\title{
Serous component is a recurrence predictive factor of grade 1 endometrioid carcinoma at stage IA: A multi-institutional and retrospective study
}

Morikazu Miyamoto ( $\square$ morikazu1118@hotmail.co.jp)

National Defence Medical College https://orcid.org/0000-0003-4763-0926

Hitoshi Tsuda

National Defence Medical College

Atsushi Sugiura

Nara Prefecture Medical College

Tsunekazu Kita

Nara Prefecture General Medical Center

Yoshitaka Kataoka

Nishisaitama-chuo National Hospital

Kenji Ishii

Nishisaitama-chuo National Hospital

Kazuya Kudo

Tama-Hokubu Medical Center

Tadashi Aoyama

National Defence Medical College

Hiroko Matsuura

National Defence Medical College

Hiroaki Soyama

National Defence Medical College

Hiroki Ishibashi

Nastional Defence Medical College

Hideki Iwahashi

National Defence Medical College

Kazuki Takasaki

National Defence Medical College

Kento Kato

National Defence Medical College

Masashi Takano

National Defence Medical College 
Research article

Keywords: Endometrial carcinoma, Grade 1 endometrioid carcinoma, Serous carcinoma, Recurrence, FIGO stage I

Posted Date: July 10th, 2019

DOI: https://doi.org/10.21203/rs.2.11175/v1

License: (c) (i) This work is licensed under a Creative Commons Attribution 4.0 International License.

Read Full License 


\section{Abstract}

Background The incidence of grade 1 endometrioid carcinoma (EG1) at 2009 International Federation of Obstetrics and Gynecology (FIGO) stage IA was the highest in endometrial carcinoma. Several studies and guidelines classified EG1 into recurrent low risk and did not recommend patients received adjuvant therapy. However, not a few case with EG1 recurred. The aim of this study was to examine whether EG1 at 2009 FIGO stage IA with a less than 5\% serous component resembling ovarian high- or low-grade serous carcinoma (SC) was a risk factor for recurrence or worse progression free survival (PFS). Methods Between 1990 and 2015, patients who received total abdominal hysterectomy and bilateral salpingooophorectomy for grade 1 endometrioid carcinoma at stage IA were enrolled at multiple centers. In addition to pathological review using 2014 World Health Organization (WHO) criteria, SC and several pathological features, including lympho-vascular invasion, were identified. A retrospective analysis to examine whether SC was a risk factor of recurrence was conducted. Results During the observational period, 236 patients were included in our study. Among them, SC was noted in 14 patients. Five patients showed recurrence and 4 of them had SC. Multivariate analysis for recurrence revealed that SC was an independent risk factor of recurrence (hazard ratio (HR) 139, $\mathrm{p}<0.001$ ). PFS of patients with SC was worse than of patients without SC $(p<0.001)$. Multivariate analysis for PFS demonstrated that SC was a significant prognostic factor (HR 98.9, $\mathrm{p}<0.0001)$. Conclusion SC was the strongest risk factor of recurrence for patients with EG1 at FIGO stage IA. Therefore, a new treatment strategy may be needed for patients with SC.

\section{Background}

In recent years, the incidence of endometrial carcinoma (EC) has been rapidly increasing around the world [1]. According to a population-based data set compiled from the National Cancer Institute's Surveillance, Epidemiology, and End Results database, the incidence of grade 1 endometrioid carcinoma (EG1) at 2009 International Federation of Obstetrics and Gynecology (FIGO) stage IA was the highest (31.7\%) among endometrioid carcinomas of all stages and all grades, and 5-year survival rates of stage IA EG ranged from $92.3 \%$ to $93.7 \%[2]$.

Standard treatment for EC is primary hysterectomy and bilateral salpingo-oophorectomy, followed by adjuvant treatment tailored according to risk classified based on the surgical specimen [3]. Recurrence risk classification was slightly different according to various trials and society guidelines. A PostOperative Radiation Therapy in Endometrial Carcinoma (PORTEC) study group, a Gynecologic Oncology Group (GOG) 99 trial, and a European Society for Medical Oncology (ESMO) guideline classified EG1 at 2009 FIGO stage IA into a low risk group [4-6]. The ESMO modified guideline and a Survival Effect of Para-Aortic Lymphadenectomy (SEPAL) study in endometrial cancer defined stage IA EG1 without lympho-vascular invasion as low recurrence risk and with lympho-vascular invasion as intermediate risk $[7,8]$. Based on the above reports, stage IA EG1 was classified into low or intermediate risk according to the status of lympho-vascular invasion. Furthermore, a systematic review by Fung-Kee-Fung et al. reveled that the overall recurrence rate was $3 \%$ or less for patients classified as low-risk (FIGO stage I, grade 1 or 
2, and one-third or less myometrial invasion) [9]. Therefore, stage IA EG1, regardless of lympho-vascular invasion, could be considered one of histological subtypes with a relatively low risk of recurrence.

On the other hand, our previous study demonstrated that a uterine serous carcinoma (SC)component in stage IA EG1, which comprised less than $5 \%$ of the total tumor area identified using an ovarian two-tiered grading system, was the primary risk factor for recurrence of EG1 at FIGO stage IA [10]. Three out of 12 (25\%) EG1 with SC recurred while 0 out of 114 (0\%) EG1 without SC recurred. Our past report also showed a component in all grades of endometrioid carcinoma resembling ovarian seromucinous carcinoma, which could have an influence on the prognosis [11]. Thus, we considered SC and seromucinous components were useful predictive factors for recurrence or prognosis. However, because our previous work was single-institutional and small-scale, the results should be confirmed by multi-institutional analyses including many more cases.

The aim of the present study was to confirm whether several factors, such as serous component, seromucinous component, and existing pathological factor, were predictive factors for the recurrence and prognosis of patients with EG1 at 2009 FIGO stage IA.

\section{Methods}

Between 1990 and 2015, patients who received total abdominal hysterectomy and bilateral salpingooophorectomy for stage IA, grade 1 endometrioid carcinoma at the National Defense Medical College Hospital, Nara Prefecture General Medical Center, Nishisaitama-chuo National Hospital, and TamaHokubu Medical Center were enrolled. Central pathological review for all patients using 2014 World Health Organization (WHO) criteria [10] was conducted (M.M. H.T.). Patients with Grade 1 endometrioid carcinoma at FIGO stage I were included in our study. Patients with complications, other carcinomas or who died due to diseases other than grade 1 EC were excluded.

Serous and seromucinous components were identified from hematoxylin and eosin slides through central pathological review according to previous reports [11,12]. Briefly, serous carcinoma (SC) which comprised less than $5 \%$ of the total volume of endometrioid carcinoma, was defined as either high-grade serous carcinoma (HGSC) or low-grade serous carcinoma (LGSC) [10]. HGSC resembled ovarian highgrade serous carcinoma and was uterine serous carcinoma. LGSC cells resembled ovarian low-grade serous carcinoma, with mild to moderate nuclear atypia characterized by the presence of slightly irregular nuclear contours and evenly distributed chromatin. Furthermore, the seromucinous component was defined as even a small focus of endocervical-type mucinous cellswith squamous differentiation, and neutrophils invading the tumors [12]. Other data was gained from clinical records at several hospitals.

JMP Pro 14 software (SAS Institute Inc., Cary, NS, the USA) was used for statistical analysis. Chisquare test and Fisher's exact test for unpaired data were used for statistical analysis. Progression-free survival (PFS) curves were obtained using the Kaplan-Meier method. Comparisons of the survival distributions were conducted using a log-rank test. Multivariable analyses to identify recurrence factors 
were based on the logistic regression method. Multivariate analysis of PFS was performed with the Cox proportional hazards model. A $p$-value $<0.05$ was considered statistically significant.

The research project was approved by the Institutional Ethical Review Board Committee of the National Defense Medical College, Tokorozawa, Japan.

\section{Results}

The median observational period was 60 months. Pathological review was conducted for a total of 260 patients. Among them, 24 patients were excluded for the following reasons: 6 patients had specimens that were not evaluable, 4 had mixed carcinoma types, 4 had no resection of bilateral uterine adnexa, 3 had diseases beyond FIGO stage IA, 2 had complications of ovarian carcinoma, 1 had serous carcinoma, 1 had cervical carcinoma, 1 died of cerebral infarction, and 1 had stomach carcinoma. In total, 236 patients were included in our study.

The analysis to identify the recurrence factors was conducted first. The recurrence rate was 5 out of $231(2.16 \%)$. Patients who showed recurrence were older $(p=0.041)$ and more had SC than those without recurrence (Table 1) $(p<0.0001)$. There was no statistical difference between the two groups for any other factor. Multivariate analysis demonstrated that presence of a serous component was the only independent factor of recurrence of those we tested (Table 2) (Hazard ratio (HR) 139.9, $p<0.001$ ).

Secondly, the analysis for survival of patients with and without SC was conducted. Patients in EG1-SC were older $(p=0.019)$ and more had lympho-vascular invasion $(p<0.001)$. During the observational period, there were no patients who died of their diseases. PFS of patients with SC was worse than those without SC. The multivariate analysis for PFS showed SC was an independent indicator of worse prognostic outcome (HR=98.9, $\mathrm{p}<0.0001)$.

The details of 5 patients who showed recurrence are shown in Table 5. There were 4 patients with SC and one patient with pure-type EG1. Among the 4 patients with SC, three $(75 \%)$ showed recurrence at distant lesions ; multiple peritoneal sites after 11 months after primary surgery, , spleen after 26 monthes, and paraaortic lymph node after 48 months, respectively, and one (25\%) patient showed recurrence at the vaginal stump after 60 months. These four patients received various treatments including resection and/or chemotherapy. The patient with pure-type EG1 showed recurrence at the vaginal stump 18 months after primary treatment and received radiotherapy.

\section{Discussion}

In our study, SC was associated with the highest risk of recurrence and was the worst prognostic factor for PFS of EG1 at stage IA. Furthermore, while 4 of $5(80 \%)$ of patients with SC showed recurrence at distant sites, one patient with pure-type EG1 showed recurrence at the vaginal stump. 
Using traditional classification of histological subtypes, endometrial carcinoma was classified into type I, low-grade, endometrioid, hormone-receptor-positive endometrial carcinoma with a good prognosis, and type II, non-endometrioid, high grade, TP53-mutated, hormone-receptor negative endometrial carcinoma with a higher risk of metastasis and a poor prognosis [4]. Endometrial serous carcinoma belonged to type II and had a worse prognosis than other type II endometrial carcinomas such as grade 3 endometrioid carcinoma [13]. A recent analysis of the Cancer Genome Atlas also demonstrated that many serous carcinomas had high copy numbers and worse prognoses [14]. Therefore, there was no doubt that serous carcinoma was the histological subtype with the poorest prognosis. Several studies demonstrated that serous carcinoma mixed with endometrial carcinoma had a clinical course similar to that of pure-type serous carcinoma [15,16]. Thus, endometrial carcinoma with serous carcinoma was also a histological subtype with a poor prognosis. These studies defined mixed endometrial carcinoma with serous component as a type I tumor with more than 5\% serous carcinoma component, similar to 2014 WHO criteria [10]. However, our previous report showed that a less than $5 \%$ serous carcinoma component was a risk factor for recurrence in grade 1 endometrioid carcinoma in a single-institutional study [12]. The present study demonstrated that SC was a risk factor for recurrence and a worse prognostic factor in a multi-institutional study. This suggests that even small foci of serous carcinoma in endometrial carcinoma are important and notable histological features.

In our study, SC was comprised of HGSC and LGSC [12]. Because tumors resembling high grade serous carcinoma corresponded to endometrial serous carcinoma in the 2014 WHO criteria [12], it was easy to identify the histological features with high malignant potential. On the other hand, Espinosa et al reported that mixed endometrial carcinomas with a low-grade, serous-like component ranging from $40 \%$ to $70 \%$ had a microcystic, elongated, or fragmented (MELF) pattern, KRAS and TP53 mutations, and aggressive behavior [17]. Similarly, our previous reports demonstrated EG1 with tumors resembling ovarian low-grade serous carcinoma also had a risk of recurrence [12]. Therefore, we considered both HGSC and LGSC were important histological features. However, because there were fewer cases with LGSC, further study is needed to examine the clinical significances of LGSC.

Several reports demonstrated that lympho-vascular invasion was a worse prognostic factor for low-risk or early-stage endometrial carcinoma [18-20]. Our study did not show the association between lympho-vascular invasion and recurrence or PFS. However, lympho-vascular invasion was more frequently discovered in EG1-SC than in pure-type EG1, which may explain the aggressive behavior of EG1-SC.

Our study showed that the recurrence rates of pure-type EG1 and EG1-SC were $0.45 \%$ and $28.57 \%$, respectively. Several reports demonstrated that patients with EG1 at stage IA required surgery alone and adjuvant therapy was not necessary $[3,4,6]$. We believed it was not necessary to perform adjuvant therapy for patients with pure-type EG1 because of the low recurrence rate. However, because of the high recurrence rate of EG1-SC, adjuvant therapy may be appropriate for these patients. Unfortunately, our study was unable to show the efficacy of adjuvant therapy for patients with EG1-SC because only one patient received it. Further study is needed to examine this. 
Our results may be useful in informing follow-up procedures after treatment. ESMO Clinical Practice Guidelines recommend follow-ups every 3-4 months with physical and gynecological examinations for the first 2 years, and then every 6 months for the next 3 years [6]. The Japan Society of Gynecologic Oncology recommends follow-ups every $1-3$ months for the first $1-3$ years after treatment, every 6 months for the fourth and fifth years after treatment, and annually from six years after treatment an on [21]. Thus, tight observation is recommended by both sets of guidelines. Based on our results, for patients with pure-type EG1, follow-ups may not be necessary because of the extremely low recurrence rate. However, patients with EG1-SC should receive tight observation using not only physical and gynecological examinations but also 'medical imaging because of the high rate of recurrence and possibility of distant metastasis. Although this assumption should be confirmed by further study, mental discomfort and medical expense could be reduced if tight observation was shifted to close observation. Because many women experience discomfort during gynecologic examination [22], unnecessary gynecologic examination should be omitted as far as possible. Hence, the Society of Gynecologic Oncologists' (SGO) clinical practice committee has a recommended frequency of follow-up of every 6 months for 1 year, then annually thereafter for patients with grade 1 or 2 endometrioid carcinoma at stage IA because of the low recurrence rate [23]. Using our concept of SC, an effective follow-up procedure for patients with stage IA EG1 could be established.

A limitation of this study is its multi-institutional but retrospective design. However, because patients with lower and higher risks of recurrence could be more precisely identified using our concept, our results could more easily distinguish patients needing adjuvant therapy from those who did not, and recommendations for post-treatment follow-up could be tailored to each patient's needs.

\section{Conclusions}

Our study showed SC was the highest risk factor of recurrence and the worst prognostic factor of PFS in EG1 at stage IA. Our results might be useful for clinical practice

\section{Abbreviations}

EC: Endometrial Carcinoma

EG1: Grade 1 Endometrioid carcinoma

FIGO: International Federation of Obstetrics and Gynecology

PORTEC: Post-Operative Radiation Therapy in Endometrial Carcinoma

GOG: Gynecologic Oncology Group

ESMO: European Society for Medical Oncology

SEPAL: Survival Effect of Para-Aortic Lymphadenectomy study 


\section{Declarations}

\section{Ethics approval and consent to participate}

All procedures performed in studies involving human participants were in accordance with the ethical standards of the institutional and/or national research committee and the 1964 Declaration of Helsinki and its later amendments or comparable ethical standards. For this type of study, formal consent is not required. For the retrospective analysis, informed consent was not obtained. This study was approved by the Clinical Research Ethics Committee of the National Defense Medical College.

\section{Consent for publication}

All data was anonymised so individual consent for publication was not applicable.

\section{Data availability}

All data analysed in this study are available from the corresponding author upon reasonable request.

\section{Conflict of interest}

All author declare no competing interest.

\section{Funding}

None.

\section{Authors' contributions}

Protocol/project development: MM, MT.

Data collection or management: AS, TK, YK, KI, KK, TA, HM, HS, HI, HI, KT, KK.

Pathological review: MM HT.

Data analysis: MM.

Manuscript writing/editing: MM, MT. 


\section{Acknowledgements}

We would like to thank Editage (www.editage.jp) for English language editing.

\section{References}

1 McAlpine JN, Temkin SM, Mackay HJ. Endometrial cancer: Not your grandmother's cancer. Cancer. 2016;122:2787-98.

2 Lewin SN, Herzog TJ, Barrena Medel NI, Deutsch I, Burke WM, Sun X, et al. Comparative performance of the 2009 international Federation of gynecology and obstetrics' staging system for uterine corpus cancer. Obstet Gynecol. 2010;116:1141-49.

3 Morice P, Leary A, Creutzberg C, Abu-Rustum N, Darai E. Endometrial cancer. Lancet. 2016;387:1094108.

4 Creutzberg CL, van Putten WL, Koper PC, Lybeert ML, Jobsen JJ, Wárlám-Rodenhuis CC, et al. Surgery and postoperative radiotherapy versus surgery alone for patients with stage- 1 endometrial carcinoma: multicentre randomised trial. PORTEC Study Group. Post Operative Radiation Therapy in Endometrial Carcinoma. Lancet. 2000;355:1404-11.

5 Keys HM, Roberts JA, Brunetto VL, Zaino RJ, Spirtos NM, Bloss JD, et al. Gynecologic Oncology Group. A phase III trial of surgery with or without adjunctive external pelvic radiation therapy in intermediate risk endometrial adenocarcinoma: a Gynecologic Oncology Group study. Gynecol Oncol. 2004;92:744-51.

6 Colombo N, Preti E, Landoni F, Carinelli S, Colombo A, Marini C, et al. ESMO Guidelines Working Group. Endometrial cancer: ESMO Clinical Practice Guidelines for diagnosis, treatment and follow-up. Ann Oncol. 2013;24:vi33-8.

7 Bendifallah S, Canlorbe G, Raimond E, Hudry D, Coutant C, Graesslin O, et al. A clue towards improving the European Society of Medical Oncology risk group classification in apparent early stage endometrial cancer? Impact of lymphovascular space invasion. Br J Cancer. 2014;110:2640-6.

8 Todo Y, Kato H, Kaneuchi M, Watari H, Takeda M, Sakuragi N. Survival effect of para-aortic lymphadenectomy in endometrial cancer (SEPAL study): a retrospective cohort analysis. Lancet. 2010;375:1165-72.

9 Fung-Kee-Fung M, Dodge J, Elit L, Lukka H, Chambers A, Oliver T. Cancer Care Ontario Program in Evidence-based Care Gynecology Cancer Disease Site Group. Follow-up after primary therapy for endometrial cancer: a systematic review. Gynecol Oncol. 2006;101:520-9. 
10 Kurman, RJ, Carcangiu, ML, Herrington, CS, Young RH. editors. WHO Classification of Tumours of Female Reproductive Organs. International Agency for Research on Cancer, Lyon, 2014.

11 Miyamoto M, Takano M, Tsuda H, Soyama H, Aoyama T, Ishibashi H, et al. Small Foci of Serous Component as a Predictor of Recurrence and Prognosis for Stage IA Endometrial Carcinomas. Oncology. 2017:93:29-35.

12 Miyamoto M, Takano M, Aoyama T, Soyama H, Yoshikawa T, Tsuda H, et al. Seromucinous component in endometrioid endometrial carcinoma as a histological predictor of prognosis. J Gynecol Oncol. 2018;29: e20.

13 Hamilton CA, Cheung MK, Osann K, Chen L, Teng NN, Longacre TA, et al. Uterine papillary serous and clear cell carcinomas predict for poorer survival compared to grade 3 endometrioid corpus cancers. Br $\mathrm{J}$ Cancer. 2006;94:642-6.

14 Kandoth C, Schultz N, Cherniack AD, Akbani R, Liu Y, Shen H, et al. Cancer Genome Atlas Research Network. Integrated genomic characterization of endometrial carcinoma. Nature. 2013;497:67-73.

15 Fader AN, Starks D, Gehrig PA, Secord AA, Frasure HE, O'Malley DM, et al. UPSC Consortium. An updated clinicopathologic study of early-stage uterine papillary serous carcinoma (UPSC). Gynecol Oncol. 2009;115:244-8.

16 Slomovitz BM, Burke TW, Eifel PJ, Ramondetta LM, Silva EG, Jhingran A, et al. Uterine papillary serous carcinoma (UPSC): a single institution review of 129 cases. Gynecol Oncol. 2003;91:463-9.

17 Espinosa I, D'Angelo E, Corominas M, Gonzalez A, Prat J. Mixed endometrial carcinomas with a "lowgrade serous"-like component: a clinicopathologic, immunohistochemical, and molecular genetic study. Hum Pathol. 2018;71:65-73.

18 Ayhan A, Şahin H, Sari ME, Yalçin I, Haberal A, Meydanli MM. Prognostic significance of lymphovascular space invasion in low-risk endometrial cancer. Int J Gynecol Cancer. 2019;29:505-12.

19 dos Reis R, Burzawa JK, Tsunoda AT, Hosaka M, Frumovitz M, Westin SN, et al. Lymphovascular Space Invasion Portends Poor Prognosis in Low-Risk Endometrial Cancer. Int J Gynecol Cancer. 2015;25:1292-9.

20 Cusano E, Myers V, Samant R, Sudai T, Keller A, Le T, et al. Prognostic Significance of Lymphovascular Space Invasion in the Absence of Lymph Node Metastases in Early-Stage Endometrial Cancer. Int J Gynecol Cancer. 2018;28:890-4.

21 Nagase S, Katabuchi H, Hiura M, Sakuragi N, Aoki Y, Kigawa J, et al; Japan Society of Gynecologic Oncology. Evidence-based guidelines for treatment of uterine body neoplasm in Japan: Japan Society of Gynecologic Oncology (JSGO) 2009 edition. Int J Clin Oncol. 2010;15:531-42. 
22 Hilden M, Sidenius K, Langhoff-Roos J, Wijma B, Schei B. Women's experiences of the gynecologic examination: factors associated with discomfort. Acta Obstet Gynecol Scand. 2003;82:1030-6.

23 Salani R, Backes FJ, Fung MF, Holschneider CH, Parker LP, Bristow RE, et al. Posttreatment surveillance and diagnosis of recurrence in women with gynecologic malignancies: Society of Gynecologic Oncologists recommendations. Am J Obstet Gynecol. 2011;204:466-78.

\section{Tables}

Table 1. Characteristics of all patients with grade 1 endometrioid carcinoma at FIGO stage IA according to recurrence.

\begin{tabular}{|c|c|c|c|c|c|}
\hline \multicolumn{2}{|l|}{ Variables } & \multicolumn{2}{|c|}{ Recurrence } & $\begin{array}{c}\text { No } \\
\text { recurrence } \\
n=231\end{array}$ & \multirow{2}{*}{$\frac{p \text {-value }}{0.0041}$} \\
\hline Age & $<60$ & 0 & $(0 \%)$ & $156 \quad(68 \%)$ & \\
\hline & $\geqq 60$ & 5 & $(100 \%)$ & $75 \quad(32 \%)$ & \\
\hline \multirow[t]{2}{*}{ Lympho-vascular Invasion } & Positive & 0 & $(0 \%)$ & $31 \quad(13 \%)$ & 0.99 \\
\hline & Negative & 5 & $(100 \%)$ & $200 \quad(87 \%)$ & \\
\hline \multirow[t]{2}{*}{ Peritoneal washing cytology } & Positive & 1 & $(20 \%)$ & $18(8 \%)$ & 0.35 \\
\hline & Negative & 4 & $(80 \%)$ & $213(92 \%)$ & \\
\hline \multirow{2}{*}{$\begin{array}{l}\text { Endocervical Glandular } \\
\text { Involvement }\end{array}$} & Positive & 0 & $(0 \%)$ & $11 \quad(5 \%)$ & 0.99 \\
\hline & Negative & 5 & $(100 \%)$ & $220 \quad(95 \%)$ & \\
\hline \multirow[t]{2}{*}{ Seromucinous Component } & Positive & 1 & $(20 \%)$ & $18(8 \%)$ & 0.35 \\
\hline & Negative & 4 & $(80 \%)$ & $213(92 \%)$ & \\
\hline \multirow[t]{2}{*}{ Mode of uterine resection } & $\begin{array}{l}\text { Radical or semi-radical } \\
\text { Hysterectomy }\end{array}$ & 1 & $(20 \%)$ & 89 (39\%) & 0.65 \\
\hline & Simple Hysterectomy & 4 & $(80 \%)$ & $142 \quad(61 \%)$ & \\
\hline \multirow[t]{2}{*}{ Pelvic lymphadenectomy } & Done & 5 & $(100 \%)$ & 187 (81\%) & 0.59 \\
\hline & Not done & 0 & $(0 \%)$ & $44 \quad(19 \%)$ & \\
\hline \multirow[t]{2}{*}{ Para-aortic lymphadenectomy } & Done & 1 & $(20 \%)$ & $52 \quad(23 \%)$ & 0.99 \\
\hline & Not done & 4 & $(80 \%)$ & $179(77 \%)$ & \\
\hline \multirow[t]{2}{*}{ Adjuvant chemotherapy } & Done & 0 & $(0 \%)$ & $23(10 \%)$ & 0.99 \\
\hline & Not done & 5 & $(100 \%)$ & $208 \quad(90 \%)$ & \\
\hline \multirow[t]{2}{*}{ Serous Component } & Positive & 4 & $(80 \%)$ & $10(4 \%)$ & $<0.0001$ \\
\hline & Negative & 1 & $(20 \%)$ & $221 \quad(96 \%)$ & \\
\hline
\end{tabular}

Table 2. Multivariate analysis of recurrence in patients with grade 1 endometrioid carcinoma at FIGO stage IA. 


\begin{tabular}{|c|c|c|c|}
\hline \multirow[b]{2}{*}{ Variables } & & Multivariate Analysis & \multirow[b]{2}{*}{$\begin{array}{c}p- \\
\text { value }\end{array}$} \\
\hline & & $\begin{aligned} \text { Hazard } & \text { (95\% Confidence } \\
\text { ratio } & \text { interval) }\end{aligned}$ & \\
\hline $\begin{array}{l}\text { Peritoneal washing } \\
\text { cytology }\end{array}$ & Positive vs. Negative & $3.702 \quad(0.102-130.114)$ & 0.471 \\
\hline $\begin{array}{l}\text { Seromucinous } \\
\text { Component }\end{array}$ & Positive vs. Negative & $6.173 \quad(0.225-169.085)$ & 0.281 \\
\hline $\begin{array}{l}\text { Mode of uterine } \\
\text { resection }\end{array}$ & $\begin{array}{l}\text { Radical or semi-radical Hysterectomy vs. } \\
\text { Simple Hysterectomy }\end{array}$ & $0.137 \quad(0.024-28.840)$ & 0.232 \\
\hline $\begin{array}{l}\text { Para-aortic } \\
\text { lymphadenectomy }\end{array}$ & Done vs. Not done & $1.199 \quad(0.035-41.465)$ & 0.920 \\
\hline Serous component & Positive vs. Negative & $139.951 \quad(10.324-1897.240)$ & $<0.001$ \\
\hline
\end{tabular}

Table 3. Characteristics of all patients with grade 1 endometrioid carcinoma at FIGO stage IA according to serous component.

\begin{tabular}{|c|c|c|c|c|c|c|}
\hline \multicolumn{2}{|l|}{ Variables } & \multicolumn{2}{|c|}{ EG1-SC } & \multicolumn{2}{|c|}{$\begin{array}{c}\text { Pure-type } \\
\text { EG1 } \\
n=222\end{array}$} & \multirow{3}{*}{$\begin{array}{l}p- \\
\text { value } \\
0.019\end{array}$} \\
\hline \multirow[t]{2}{*}{ Age } & $<60$ & 5 & $(35.7 \%)$ & 151 & $(68.0 \%)$ & \\
\hline & $\geqq 60$ & 9 & $(64.3 \%)$ & 71 & $(32.0 \%)$ & \\
\hline \multirow[t]{2}{*}{ Lympho-vascular Invasion } & Positive & 7 & $(50.0 \%)$ & 24 & $(10.8 \%)$ & $<0.001$ \\
\hline & Negative & 7 & $(50.0 \%)$ & 198 & $(89.2 \%)$ & \\
\hline \multirow[t]{2}{*}{ Peritoneal washing cytology } & Positive & 1 & $(7.1 \%)$ & 18 & $(8.1 \%)$ & 0.999 \\
\hline & Negative & 13 & $(92.9 \%)$ & 204 & $(91.9 \%)$ & \\
\hline \multirow{2}{*}{$\begin{array}{l}\text { Endocervical Glandular } \\
\text { Involvement }\end{array}$} & Positive & 0 & $(0 \%)$ & 11 & $(5.0 \%)$ & 0.999 \\
\hline & Negative & 14 & $(100 \%)$ & 211 & $(95.0 \%)$ & \\
\hline \multirow[t]{2}{*}{ Seromucinous Component } & Positive & 2 & $(14.3 \%)$ & 17 & $(7.7 \%)$ & 0.313 \\
\hline & Negative & 12 & $(85.7 \%)$ & 205 & $(92.3 \%)$ & \\
\hline \multirow[t]{2}{*}{ Mode of uterine resection } & $\begin{array}{l}\text { Radical or semi-radical } \\
\text { Hysterectomy }\end{array}$ & 6 & $(42.9 \%)$ & 84 & $(37.8 \%)$ & 0.779 \\
\hline & Simple Hysterectomy & 8 & $(57.1 \%)$ & 138 & $(62.2 \%)$ & \\
\hline \multirow[t]{2}{*}{ Pelvic lymphadenectomy } & Done & 11 & $(78.6 \%)$ & 181 & $(81.5 \%)$ & 0.729 \\
\hline & Not done & 3 & $(21.4 \%)$ & 41 & $(18.5 \%)$ & \\
\hline \multirow[t]{2}{*}{ Para-aortic lymphadenectomy } & Done & 3 & $(21.4 \%)$ & 50 & $(22.5 \%)$ & 0.999 \\
\hline & Not done & 11 & $(78.6 \%)$ & 172 & $(77.5 \%)$ & \\
\hline \multirow[t]{2}{*}{ Adjuvant chemotherapy } & Done & 1 & $(7.1 \%)$ & 22 & $(9.9 \%)$ & 0.999 \\
\hline & Not done & 13 & $(92.9 \%)$ & 200 & $(90.1 \%)$ & \\
\hline \multirow[t]{2}{*}{ Recurrence } & Yes & 4 & $(28.5 \%)$ & 1 & $(0.5 \%)$ & $<0.001$ \\
\hline & No & 10 & $(71.5 \%)$ & 221 & $(99.5 \%)$ & \\
\hline
\end{tabular}


Table 4. Multivariate analysis of progression-free survival in patients with grade 1 endometrioid carcinoma at FIGO stage IA.

\begin{tabular}{|c|c|c|c|c|}
\hline \multirow[b]{2}{*}{ Variables } & & \multicolumn{2}{|c|}{ Multivariate Analysis } & \multirow[b]{2}{*}{$p$-value } \\
\hline & & $\begin{array}{r}\text { Hazard } \\
\text { ratio }\end{array}$ & $\begin{array}{l}\text { (95\% Confidence } \\
\text { interval) }\end{array}$ & \\
\hline $\begin{array}{l}\text { Peritoneal washing } \\
\text { cytology }\end{array}$ & Positive vs. Negative & 3.101 & $(0.070-105.229)$ & 0.515 \\
\hline $\begin{array}{l}\text { Seromucinous } \\
\text { Component }\end{array}$ & Positive vs. Negative & 3.875 & $(0.113-128.609)$ & 0.416 \\
\hline $\begin{array}{l}\text { Mode of uterine } \\
\text { resection }\end{array}$ & $\begin{array}{l}\text { Radical or semi-radical Hysterectomy vs. } \\
\text { Simple Hysterectomy }\end{array}$ & 0.127 & $(0.003-1.778)$ & 0.141 \\
\hline $\begin{array}{l}\text { Para-aortic } \\
\text { lymphadenectomy }\end{array}$ & Done vs. Not done & 0.926 & $(0.017-19.261)$ & 0.416 \\
\hline Serous component & Positive vs. Negative & 98.900 & (13.151-2393.123) & $<0.0001$ \\
\hline
\end{tabular}

Table 5. Details of 5 patients who showed recurrence.

\begin{tabular}{|c|c|c|c|c|c|c|c|}
\hline Case & $\begin{array}{l}\text { Histological } \\
\text { type }\end{array}$ & Primary surgery & $\begin{array}{l}\text { Adjuvant } \\
\text { treatment }\end{array}$ & $\begin{array}{l}\text { The site at } \\
\text { recurrence }\end{array}$ & $\begin{array}{l}\text { Treatment at } \\
\text { recurrence }\end{array}$ & $\begin{array}{l}\text { Duration from } \\
\text { primary } \\
\text { treatment } \\
\text { until } \\
\text { recurrence }\end{array}$ & $\begin{array}{l}\text { Outcome } \\
\text { primary } \\
\text { treatment }\end{array}$ \\
\hline 1 & EG1-SC & $\begin{array}{l}\text { Simple } \\
\text { hysterectomy }+ \\
\text { pelvic } \\
\text { lymphadenectomy }\end{array}$ & Not done & $\begin{array}{l}\text { Vaginal } \\
\text { stump + } \\
\text { Spleen } \\
\text { metastasis }\end{array}$ & $\begin{array}{l}\text { Tumor } \\
\text { resection at } \\
\text { vaginal stump } \\
+ \\
\text { chemotherapy }\end{array}$ & 26 & $\begin{array}{l}\text { Alive with } \\
\text { disease } \\
\text { for } 26 \\
\text { months }\end{array}$ \\
\hline 2 & EG1-SC & $\begin{array}{l}\text { Semi-radical } \\
\text { hysterectomy }+ \\
\text { pelvic } \\
\text { lymphadenectomy }\end{array}$ & Not done & $\begin{array}{l}\text { Vaginal } \\
\text { stump }\end{array}$ & $\begin{array}{l}\text { Tumor } \\
\text { resection }\end{array}$ & 60 & $\begin{array}{l}\text { Alive } \\
\text { without } \\
\text { disease } \\
\text { for } 73 \\
\text { months }\end{array}$ \\
\hline 3 & EG1-SC & $\begin{array}{l}\text { Simple } \\
\text { hysterectomy + } \\
\text { pelvic } \\
\text { lymphadenectomy }\end{array}$ & Not done & $\begin{array}{l}\text { Paraaortic } \\
\text { lymph } \\
\text { node }\end{array}$ & $\begin{array}{l}\text { Tumor } \\
\text { resection }+ \\
\text { chemotherapy }\end{array}$ & 48 & $\begin{array}{l}\text { Alive } \\
\text { without } \\
\text { disease } \\
\text { for } 85 \\
\text { months }\end{array}$ \\
\hline 4 & EG1-SC & $\begin{array}{l}\text { Simple } \\
\text { hysterectomy }+ \\
\text { pelvic } \\
\text { lymphadenectomy }\end{array}$ & Not done & $\begin{array}{l}\text { Multiple } \\
\text { peritoneal } \\
\text { metastasis }\end{array}$ & Chemotherapy & 11 & $\begin{array}{l}\text { Alive with } \\
\text { disease } \\
\text { for } 52 \\
\text { months }\end{array}$ \\
\hline 5 & $\begin{array}{l}\text { Pure-type } \\
\text { EG1 }\end{array}$ & $\begin{array}{l}\text { Simple } \\
\text { hysterectomy }+ \\
\text { pelvic } \\
\text { lymphadenectomy }\end{array}$ & Not done & $\begin{array}{l}\text { Vaginal } \\
\text { stump }\end{array}$ & Radiotherapy & 18 & $\begin{array}{l}\text { Dead of } \\
\text { disease } \\
\text { for } 43 \\
\text { months }\end{array}$ \\
\hline
\end{tabular}

